\title{
Regimen Used to Treat Malignant Ovarian Neoplasm
}

National Cancer Institute

\section{Source}

National Cancer Institute. Regimen Used to Treat Malignant Ovarian Neoplasm. NCI

Thesaurus. Code C63522.

Any regimen that can be used for the treatment of malignant ovarian neoplasm. 